and noteworthy, and the authors adequately discuss their implications.

Perhaps because their focus was on autobiographical memory, the authors do not emphasise the implications of the DAS results, which I believe are also important. The implications are twofold. Firstly, with respect to the state v. trait marker issue, the DAS results are consistent with Beck et als (1979) cognitive theory of depression, in that dysfunctional attitudes did not significantly change as depression remitted (i.e., behaved as a trait marker would). This is particularly important in light of the controversy over whether cognitive styles are indeed trait-like depressogenic vulnerability factors (see for example, Coyne \& Gotlib, 1983).

Secondly, although it is not unreasonable to compare the autobiographical memory measure to the DAS in predicting depression at follow-up, it should be noted that Beck et $a$ l's (1979) theory predicts an association between dysfunctional attitudes and future depression in the presence, but not the absence, of negative life stress (see Haaga \& Beck, 1992 for a recent treatment of this issue). Put differently, the theory contains a diathesis-stress component, and both the diathesis (dysfunctional attitudes) and the stress (negative life stress) are necessary to initiate the sequence towards depression. Because the Brittlebank et al (1993) study did not assess negative life stress, the study cannot speak for the validity of this aspect of the theory, neither with respect to predicting future depression, nor treatment response.

Beck, A. T., Rush, A. J., Shaw, B. F., et al (1979) Cognitive Therapy of Depression. New York: Guilford.

CoYNE, J. C. \& Gotur, I. H. (1983) The role of cognition in depression: a critical appraisal. Psychological Bulletin, 94, 472-505.

HaAga, D. A. F. \& Beck, A. T. (1992) Cognitive therapy. In Handbook of Affective Disorders (ed. E. Paykel), pp. 511-523. New York: Guilford.

Weassman, A. N. (1979) The dysfunctional attitude scale: a validation study. Dissertation, University of Pennsylvania. Dissertation Abstracts International, 40, 1389-1390B.

University of Texas at Austin and

THOMAS E. JOINER, JR

O.E. Teague Veterans' Affairs Medical Center

Psychology Service (116B)

Temple, Texas 76504 USA

\section{Blood-letting in bulimia nervosa}

SIR: In their recent article, Drs Parkin \& Eagles (Journal, February, 1993, 162, 246-248) wrote that "there does not appear to be any reference in the literature to deliberate blood-letting (...) in association with eating disorders". It is indeed a rare association and, in my own clinical work with eating disordered patients over the past 15 years, I have seen it only once in a nurse with chronic anorexia nervosa. Nevertheless, I have found a few references in the literature. In a comment on "Blood-letting as purging behaviour" Cosman 1986 briefly presents the case of a 26-year-old woman. In the French literature, deliberate blood-letting has been described by Jean Bernard (1969) under the term "syndrome of Lasthénie de Ferjol", named after the heroine in a 19th century French novel by Barbey d'Aurévilly. A relationship between this syndrome and anorexia nervosa has been suggested by the Flemish psychiatrist Myriam Van Moffaert (1976). Finally, the similarities have been discussed by Loloum et al (1985).

These French authors present the case of a 26year-old woman with anorexia nervosa (fasting alternating with binge-eating episodes) who, during her brilliant nursing studies, started blood-letting herself several times a week.

Bernard, J. (1969) Le syndrôme de Lasthénie de Ferjol. Actualités Hématologiques, 3, 3-8.

Cosman, B. C. (1986) Blood-letting as purging behavior. American Journal of Psychiatry. 143, 1188-1189.

Loloum, T., Susnn, J. R. \& P. Deniker (1985) Le syndrome de Lasthénie de Ferjol et l'anorexie mentale: de troublantes similitudes. Annales Médico-Psychologiques, 143, 488-494.

Van Moffaert, M. (1976) Het Syndroom van Lasthénie de Ferjol. Tijdschrift voor Psychiatrie, 18, 25-34.

University of Leuven

W. VANDEREYCKEN

Leuvenselaan 85

B-3300 Tienen

Belgium

Tourette's syndrome and the amygdaloid complex

I was interested to read the thought-provoking commentary by Handley et al (Journal, March 1993, 162, 421) on my article (Jadresic; Journal, October 1992, $161,532-534$ ) which advocates a key role for the amygdaloid complex (AC) in Tourette's syndrome (TS).

One of their contentions is that the cadence, pitch, volume, etc., in the coprolalia of TS differs from that of purely emotionally generated obscenity and this would therefore militate against the involvement of the amygdala in TS. The verbal as opposed to the prosodic aggressive content of vocalisations raises interesting theoretical links with models of laterality in brain function. This model includes the well known association of the dominant hemisphere with verbal aspects of language and the more controversial association of non-dominant hemisphere involvement in prosodic aspects of language 